\title{
Utopiens grænser i Den amerikanske revolution
}

\section{Om utopiske tekststrategier $i$ Common Sense og Letters from an American Farmer}

Politiske revolutioner er ikke utopier. Som oftest tager revolutioner deres udgangspunkt i en konkret konflikt og udvikler sig som en stadig mere omfattende magtkamp mellem forskellige grupper. Der er på den måde meget realpolitik i revolutioner, selvom der naturligvis er tale om en radikal udvidelse af de politiske handlemuligheder. Utopier er omvendt heller ikke revolutioner - ofte udfolder utopiske forestillinger sig helt løsrevet fra idéer om, hvordan et alternativt samfund skal bringes til veje. Alligevel kan utopi og revolution ikke helt skilles ad. Begge har et forhold til forandringens problematik og udfordrer grænserne mellem det mulige og det umulige.

Jeg vil her undersøge, hvordan forholdet mellem litteratur, utopi og revolution bliver bearbejdet i to tekster fra årene omkring Den amerikanske revolution: Tom Paines Common Sense fra 1776 og J. Hector St. John de Crèvecoeurs Letters from an American Farmer fra 1782. Begge står centralt i tidlig amerikansk litteratur, men på forskellige måder. Crèvecoeurs Letters har bevæget sig mellem delvis glemsel og en kanoniseret status som en af de tidligste formuleringer af en særlig amerikansk identitet. Crèvecoeur var oprindeligt en veluddannet franskmand, der tog til Amerika og slog sig ned som bonde efter at have deltaget i kolonikrigen mellem England og Frankrig. Letters blev først udgivet i London, efter at han var flygtet tilbage til Europa for at undslippe revolutionens farer. Herfra fik teksten i første omgang en stor udbredelse i Europa for først i løbet af de efterfølgende årtier at opnå en bredere cirkulation i USA. Benjamin Franklin anbefalede den til europæere, der overvejede at emigrere.

Paine - der som englænder ligeledes var en nyligt indvandret europæer - indtager en på én gang central og marginal rolle i fortællingen om revolutionen, idet han på den ene side fremstod som en kompromisløs propagandist for revolutionen, men på den anden side efterfølgende ragede uklar med flere af sine tidligere kampfæller, ikke mindst George Washington, bl.a. i forbindelse med sin deltagelse i Den franske revolution (et spørgsmål, der splittede de amerikanske revolutionære). Efter godt 
et årti med en række konfrontationer mellem kolonierne og kolonimagten, ${ }^{\mathrm{I}}$ bl.a. om beskatning, var Common Sense blandt de første entydige opfordringer til amerikansk selvstændighed fra Storbritannien, og pamfletten fik en hidtil uset udbredelse.

De to tekster placerer sig vidt forskelligt i revolutionens offentlige rum. Der er tale om to markant forskellige genrer og udsigelsespositioner med Paines offentlige pamfletdiskurs over for Crèvecoeurs pseudo-private brevdiskurs. Paine lader tilsyneladende det skrivende subjekt skinne klart og utvetydigt igennem teksten samtidig med at Common Sense oprindeligt blev udgivet anonymt. Crèvecoeur på sin side lader sine breve fremstå som autentiske tekster skrevet af en amerikansk bonde (James) - selvom de er fiktive, men samtidig også henviser til Crèvecoeurs egne erfaringer med at slå sig ned som bonde i Amerika. ${ }^{2}$

Hverken Paine eller Crèvecoeur falder naturligt ind i en kanon over utopisk litteratur; en tradition, der har sit navn fra Thomas Mores Utopia fra 1516. Flere utopier fra renæssancen og frem har på forskellige måder taget udgangspunkt i opdagelsen af 'den nye verden', der har kunnet fungere som en oplagt kilde til forestillinger om alternative måder at indrette sig på. Netop denne nye verden er i sagens natur også udgangspunktet for Paine og Crèvecoeur, men som en anderledes konkret realitet. Samtidig tager deres tekster sig ikke formmæssigt ud som klassiske utopier, hvor et helt samfunds indretning, fra forfatning til levevis, beskrives. Et centralt karakteristikum ved utopiske tekster er dog, at de inkorporerer og bearbejder forskellige typer af diskurser og genrer. ${ }^{3}$ Ikke mindst overskrider de skellet mellem fiktive og ikke-fiktive teksttyper, hvilket vi også ser hos Paine og Crèvecoeur (som Fredric Jameson skriver: "utopias are non-fiction, even though they are also non-existent" (Jameson 2004, 54)). Min tilgang til den utopiske tekst vil derfor snarere se den som en tekstpraksis, der går imellem og på tværs af forskellige diskurser og genrer end som en relativt stabil litterær genre. Det afgørende er, at utopien i denne diskursive udveksling kan siges at betegne en specifik tekstuel funktion, som bearbejder ideologiske brudflader og modsætninger. Det er en funktion, der består i produktionen af et 'ikke-sted' eller et 'ikke-rum'; det alternativ, der ikke eksisterer, men som samtidig er (tekstuelt) produceret og herigennem fungerer som en udfordring af ideologiske og diskursive grænser. Ikke mindst handler det om dette ikke-steds funktion i forhold til en omgivende politisk og social realitet - og utopiens grundlæggende og uløselige problematik har altid været spørgsmålet om, hvorvidt den utopiske vision skal og kan realiseres eller ej. Heraf opstår utopiens modsætninger. ${ }^{4}$

Logikken i den utopiske teksts funktion involverer i denne optik en fremstilling af utopiske figurer, der producerer betydningsmæssige nulpunkter og overskud i bearbejdningen af billeder af og fortællinger om sociale og politiske rum. ${ }^{5}$ Både Crèvecoeurs og Paines tekst arbejder med udgangspunkt i mulighederne for at konstruere et nyt 'socialt rum' på det amerikanske kontinent, men de forholder dette projekt til den politiske revolution på ganske forskellige måder. En utopisk funktion står centralt i begge teksters måde at fungere på, men denne funktion tjener i det ene tilfælde til at inspirere den politiske revolution, i det andet er den en reaktion mod samme. Læst sammen fremstiller teksterne på den måde en modsætning i utopien som sådan - og i sammenhæng hermed ses i begge tilfælde også en modstand mod utopien; en form for 'anti-utopisk impuls' i utopien. 
Jeg vil forfølge to spor, som hen ad vejen gerne skulle komme i berøring med hinanden. Det ene analyserer, hvordan teksterne producerer en utopisk funktion eller et 'utopisk overskud', og hvordan utopiens modsætninger er indlejrede i denne funktion. Det andet spor ser på utopiens modsætningsfyldte forhold til det politiske. 'Det politiske' kan grundlæggende siges at bestå i den strategiske kamp om statsmagten. Denne magtkamp er også central i revolutionen som fænomen, men samtidig udvides koordinaterne så at sige, idet kampen også bliver et spørgsmål om statens (og måske samfundets) udformning som sådan - og i den revolutionære proces tillægges det politiske netop herved en utopisk dimension. ${ }^{6}$ I forlængelse heraf kan man sige, at det er i mødet med den politiske revolution, at nogle af utopiens indbyggede modsætninger bliver tydelige, idet disse netop kredser om spørgsmålet om realiseringen/ikke-realiseringen af utopiens ikke-sted. Jeg skal vende tilbage til de to tekster om et øjeblik; først nogle mere generelle bemærkninger om (litteratur i) Den amerikanske revolution.

\section{Litteratur i Den amerikanske revolution}

I modsætning til revolutioner som den engelske, den franske og den russiske, der alle har en omdiskuteret status i de respektive nationale selvforståelser, er Den amerikanske revolution entydigt indskrevet i USA's ideologiske selvbillede. Og det er et billede, der bl.a. baserer sig på en idé om en form for utopisk dimension forbundet med den særlige amerikanske virkelighed - så på den måde kan fortællingen om Den amerikanske revolution ses som et godt eksempel på Fredric Jamesons tese om, at ideologi er utopisk, og utopi er ideologisk (Jameson 2007a, 271-90). Det er dog ikke den senere skabte myte om Den amerikanske revolution, jeg vil beskæftige mig med her, men ved at analysere disse to væsentlige tekster fra perioden kan det være muligt at pege på nogle flere modsætninger i revolutionens utopiske potentiale.

Den amerikanske revolutions centrale moment er Uafhængighedserklæringen i 1776. Forinden er gået godt et årtis større og mindre konfrontationer mellem kolonister og kolonimagt, og efterfølgende ligger godt et halvt årtis krig mod Storbritannien indtil underskrivelsen af fredsaftalen i 1783. Noget af det karakteristiske ved Den amerikanske revolution er bl.a. sammenhængen mellem kampen for uafhængighed af kolonimagten og kampen imod monarki og for en republikansk styreform. Disse to sammenhængende bevægelser forbinder på den måde det geografiske rum med udviklingen af en ny politisk form.

Den amerikanske revolution var dog langt fra nogen homogen affære. Til trods for at der langt hen ad vejen var tale om en proces, der blev ledet ovenfra af folk som John Adams, Thomas Jefferson, George Washington og James Madison, så var andre sociale grupper og politiske dagsordener (både radikale og loyalistiske) også en del af revolutionen.7 Det kom bl.a. til udtryk i Vermonts løsrivelse fra New York og efter Uafhængighedskrigen i kontroverserne omkring den nye forfatning (vedtaget i 1787) mellem føderalistiske tilhængere og anti-føderalistiske modstandere af forfatningen samt i større og mindre oprør fra forskellige grupper af bønder (i 'Shay's Rebellion' (1786-87) og 'the Whiskey Rebellion' (1790'erne)). Produktionen af forskellige utopiske perspektiver og funktioner skal også ses som en del af den 
komplekse og modsætningsfulde revolutionsproces og de forskellige ideologiske og diskursive brydninger, den resulterede $\mathrm{i}$.

Som andre, især tidlige moderne, revolutioner er også Den amerikanske revolution præget af en dobbelthed i sin historiske selvforståelse, der både markerer et brud med den hidtidige historie og samtidig involverer en genopdagelse af klassiske traditioner. Således ligger der i Den amerikanske revolution en bearbejdning af en republikansk tradition, der løber fra renæssancen til den engelske revolution, og som møder et nyt, åbent rum i form af det amerikanske kontinent. ${ }^{8}$ Republikanismen kan som en modsætningsfuld diskursiv og politisk strømning siges at rumme både utopiske og anti-utopiske elementer, ligesom den både kan tillægges en radikal og en konservativ vægtning. I denne sammenhæng er det samtidig væsentligt, at den republikanske tradition og det republikanske projekt er forbundet med en stærk bevidsthed om betydningen af en oplyst, uddannet (men ikke nødvendigvis bred og inkluderende) offentlighed og om skriftens betydning. Litteratur - i bred forstand vel at mærke - spillede en væsentlig rolle i Den amerikanske revolution og i den udformning af en republikansk kultur og offentlighed, der fandt sted i årene omkring den. Michael Warner skriver om litteratur og offentlighed under revolutionen:

Uf The crisis surrounding the Stamp Act [1765, mbj], moreover, had the effect of strengthening the identification of print culture and republicanism. The more anti-British sentiment grew, the more writing and print became the mode of resistance. And the more writing and print were used to mobilize the political, the more the political came to be defined in ways alien to the British legitimation of power. (Warner 1990, 71)

I både Paines og Crèvecoeurs tekster spiller bevidstheden om såvel tekstmediets betydningspotentiale som dets begrænsninger en rolle i produktionen af de tekstuelle (og utopiske) strategier.

Edward Larkin skriver om brugen af tekster i Den amerikanske revolution: " $[\mathrm{N}]$ o form of writing was published more frequently or read so widely at the time as political polemics." Og videre om den manglende interesse for Tom Paine som litterær figur: "Paine's fate illustrates how we have continued to produce a version of the Revolution that dichotomizes literature and politics by separating writing into modern categories that do not adequately represent the complexity of eighteenth-century culture" (Larkin 2005, 177). ${ }^{9}$ Det peger altså på en sammensat litterær kultur i tæt sammenhæng med en politisk offentlighed og dennes ideologiske brydninger. Det er også som et produkt af nogle af disse udvekslinger og brudflader, jeg i det følgende vil betragte teksternes utopiske funktion. Som nævnt kommer utopiens modsætningsfyldte karakter især til udtryk i forholdet til det politiske, og i denne forbindelse konfronterer utopi og politik netop hinanden i revolutionen, der rejser spørgsmålet om, hvorvidt en utopi skal og kan realiseres eller ej. Her truer den politiske revolution så at sige med at realisere ikke-stedets immaterielle virkelighed, og på den måde skæres der i den revolutionære kontekst ind til benet af utopiens grundlæggende modsætningsforhold. Derfor bearbejder teksterne også revolutionen på forskellige måder: Hvor Paine skriver den mest berømte opfordring 
til amerikansk selvstændighed godt et halvt år før vedtagelsen af Uafhængighedserklæringen, skriver Crèvecoeur en tekst, der er anderledes foruroliget over den revolutionære politiks (både fysiske og symbolske) voldsomhed.

I det følgende vil jeg skitsere, ikke bare hvordan disse to tekstuelle strategier søger at producere utopiske rum på forskellige måder, men også hvordan de, netop når de læses sammen, bringer utopiens modsætningsfyldte logik tydeligere frem. Et centralt aspekt i denne læsning er et fokus på teksternes utopiske figurer - så hvilke former for utopiske figurer kan identificeres her? I begge tekster består produktionen af en utopisk funktion i høj grad i at etablere og krydse konkrete og symbolske grænser..$^{10}$ Det er bl.a. denne grænsekonstruerende og -overskridende dimension, jeg vil se nærmere på nedenfor. Endvidere er denne grænse-figur forbundet med, hvad der kunne betegnes som en i bred forstand 'ikonoklastisk' dimension - her i kraft af teksternes forskellige bearbejdninger af kongemagtens symbolske status. Hvordan disse figurer konkret arbejder i teksterne, vil jeg se nærmere på nedenfor.

\section{Atlanterhavet vs. the Frontier:}

\section{Den amerikanske revolutions to grænser}

Det er et på mange måder utopisk billede af mulighederne i Amerikas nye verden, vi får skildret igennem størstedelen af Crèvecoeurs Letters from an American Farmer også selvom teksten ikke præsenterer en utopi, der er baseret på materiel overflod, men på friheden til at etablere sig selv og arbejde hårdt. Jeg vil dog her fokusere på det sidste, mere problematiserende brev, "Distresses of a Frontier-Man". ${ }^{\text {II }}$ Dette sidste kapitel i Letters skaber en interessant konstruktion, hvor den i forvejen etablerede utopi (det amerikanske kolonisamfund) udfordres. Størstedelen af bogen består i en beskrivelse af James' og andre amerikaneres liv og værdier. Men i bogens sidste del tvinger revolutionen James til at foretage endnu en grænseoverskridende bevægelse, idet han føler sig nødsaget til sammen med sin familie at søge tilflugt hos en venligsindet indianerstamme for at komme på sikker afstand af krigshandlingerne (som nævnt foretog Crèvecoeur selv den modsatte bevægelse, idet han flygtede tilbage til Europa) - så hermed opstilles en ny utopisk konstruktion. Der skydes så at sige endnu et utopisk niveau (indianersamfundet) ind under Den amerikanske utopis niveau.

Denne kombination af at etablere og samtidig overskride grænser ses også i den sidste del af Common Sense. Her gør Paine en del ud af mulighederne for at skabe en amerikansk flåde, der kan hamle op med den britiske. Det kan umiddelbart synes som en litterært set uinteressant del af Paines pamflet - og det er det måske også med f.eks. opremsningen af omkostningerne ved skibe af forskellige typer. Men samtidig rummer dette afsnit en dimension, som peger på nogle af de markante utopiske træk ved Paines tekst, og "den potentielle flåde" er på den måde med til at skabe billedet af Paines Amerika og utopi. Selv tillægger Paine den mulige flåde stor betydning: "No country on the globe is so happily situated, or so internally capable of raising a fleet as America" (Paine 1995, 38). Og videre: "Ship-building is America's greatest pride" (s. 39).

Diskussionen af den potentielle amerikanske flåde tillader Paine at fremhæve 
flere centrale træk ved sin forståelse af både den aktuelle situation og af Den amerikanske virkelighed som sådan. For det første understreges Atlanterhavets dobbelte funktion som en grænse og en åbning. For det andet beskrives det enorme potentiale, der for Paine ligger i det amerikanske kontinent - i sammenhængen mellem naturen, samfundet og befolkningen. Det er et uforarbejdet og ubegrænset potentiale til produktion, som amerikanerne står over for, og de kan derfor forme deres virkelighed, som de vil. Og det er netop en central pointe i Common Sense's billede af Amerika: De amerikanske koloniers 'uudviklede' stadium er en væsentlig grund til, at selvstændighed er en god idé, idet de nye samfund har ungdommens friskhed og styrke. 'Flåden' kommer altså til at fungere som en art utopisk metonymi for og funktion af Amerikas demokratiske og produktive potentiale på den ene side og på den anden for den afskæring fra det monarkistiske Europa, der samtidig er en åbning for alle verdens frihedssøgende folk.

De forskellige grænsemarkeringer hos Paine og Crèvecoeur får på den måde en væsentlig betydning for teksternes forskellige produktioner af utopiske rum: Hvor Paine på sin side søger at fremstille Amerika som en 'utopi-i-verden', så bevæger Crèvecoeur sig på den anden side ned i skala til en 'utopi-i-Amerika'. Der er altså tale om to forskellige rumlige bevægelser og konstruktioner - i det ene tilfælde en overskridelse, i det andet en tilbagetrækning.

\section{Den simple verdens stil}

Der er ikke nødvendigvis noget nyt $i$ at beskrive Tom Paine som en utopisk forfatter. Eric Foner skriver f.eks.: "Paine transformed the language of an impending millennium into the secular vision of a utopia in the New World" (Foner 1977, 81). Mark Jendrysik (2007) påpeger dog, at selvom Foner betegner Paine som utopist, så forklarer han ikke nærmere, hvad der ligger i den betegnelse. Jendrysik fors $\varnothing$ ger selv at udlægge, hvad der er utopisk hos Paine, og peger i den forbindelse på flere relevante aspekter, bl.a. med henvisning til Russell Jacobys skelnen mellem 'utopisk model' og 'utopisk ikonoklasme' (Jacoby 2005). Jendrysik relaterer dog ikke denne diskussion af Paine til hans teksters litterære dimension eller funktionsmåde, hvad der ellers vil kunne åbne for en forståelse af utopien som en tekstuel funktion frem for blot en idé.

Et centralt element i Paines litterære strategi består i en nedbrydning (eller 'dekonstruktion' om man vil) af hierarkier og modsætninger (såsom høj/lav, fornuft/ følelse, offentlig/privat). Både i teksternes indhold og igennem deres form og stil. Der er f.eks. tydeligt i Common Sense i den indledende latterliggørelse af monarkiet som institution, der er et godt eksempel på en ikonoklastisk retorik, ${ }^{12}$ og som samtidig etablerer en egalitær logik som et afgørende element i tekstens strategi (Paine 1995, 12-20). Og generelt er Common Sense kendetegnet ved sin særlige stil: Den præsenterer sig ikke som en klassisk politisk traktat, der søger at skrive sig ind i en tradition af politiske tænkere, men i stedet som en pamflet skrevet i et lettilgængeligt sprog henvendt til en bredere offentlighed. I tekstens egen selvforståelse og -iscenesættelse er der tale om 'almindelig sund fornuft', som den vokser ud af den konkrete erfaring. På den måde er Common Sense en bestemt form for tekstuel 
praksis, der også i sin formelle konstruktion og med sin diskursive positionering søger at nedbryde traditionelle stilistiske og genremæssige hierarkier og etablere en mere inkluderende litterær offentlighed. ${ }^{13}$

Denne (ikonoklastiske) nedbrydning af hierarkier fungerer her som en væsentlig forudsætning i en tekststrategi, der sigter mod at etablere et potentielt ikke-sted som udgangspunkt for en utopisk vision. I det virkelighedsbillede, Paine herigennem får fremskrevet, er det i høj grad 'det simple', der er omdrejningspunktet for både det utopiske indhold og den litterære form: Teksten formidler direkte den enkle sandhed om verden. "I draw my idea of the form of government from a principle in nature, which no art can overturn, viz. that the more simple any thing is, the less liable it is to be disordered, and the easier repaired when disordered" (Paine, 9). Paines formuleringer her antyder i øvrigt en ikke ubetydelig modsætning: Den politiske form er på én gang naturlig og kunstig; både udtryk for ahistoriske naturlove og et produkt af menneskelig planlægning. Modsætningen mellem det kunstige og det naturlige får også karakter af en bestemt måde at fremstille forholdet mellem tekst og verden på, og idet distinktionen i Paines tekst netop bliver utydelig, synes disse to poler så at sige at glide sammen. På den måde kan man se, at det Amerika, vi møder i Paines tekst, langt hen ad vejen har karakter af et endnu ikke realiseret potentiale, og det er dét, han skriver frem i sin tekst.

Det simple og enkle står også centralt i Crèvecoeurs litterære projekt: "Not a word of politics shall cloud our simple conversation" (Crèvecoeur 2009, 215). Sådan beskriver fortælleren i Letters den tilstand, han forestiller sig, når han og hans familie har søgt tilflugt hos indianerstammen. Idealet er den simple, umiddelbare tilværelse, der ikke er skæmmet af politikkens komplekse verden, diskussioner og abstrakte principper.

I løbet af Letters har Crévecoeur gennem den fiktive bonde James' breve opridset de ifølge ham væsentligste træk ved det stadig relativt nye amerikanske samfund. Det er først og fremmest et landbrugssamfund med dyder som arbejdsomhed, ædruelighed og et fokus på det nære, især familien. Crèvecoeurs fortæller påtager sig også en 'ulærd' tilgang til sit skriveprojekt, idet han til at begynde med er i tvivl om, hvorvidt det at skrive overhovedet er noget, han bør give sig i kast med - men han lader sig overbevise om, at han godt kan skrive, hvis han blot har samme tilgang, som hvis han samtalte frit med en anden person og dermed ikke var bundet af nogen litterære krav og konventioner (s. 11-23). Som i Paines tekst arbejdes der altså også her med en iscenesat autenticitet, der søger at placere tekstens udsigelsesposition så tæt ved naturens, arbejdets og folkets virkelighed som muligt.

\section{Litteraturens republikanske modsætninger}

Det er naturligvis væsentligt at holde fast $i$, at såvel Paines som Crèvecoeurs ubearbejdede og umiddelbare 'sunde fornuft' i høj grad er en (utopisk) konstruktion (jf. den politiske form som både naturlig og kunstig). Paine var givetvis ikke så fremmed over for traditionen og klassikerne, som han søger at give indtryk af. ${ }^{14} \mathrm{Og}$ han lader da også et enkelt citat af John Milton snige sig ind i Common Sense: "never can true reconcilement grow where wounds of deadly hate have pierced so deep" 
(Paine 1995, 27). Citatet er fra Paradise Lost, hvor (den oprørske) Satan erklærer, at forsoning med (den tyranniske) Gud ikke er mulig (Milton, bog IV, vv. 98-99). Paine placerer sig her tilsyneladende sammen med de Milton-læsere (f.eks. Thomas Jefferson!), der var fascinerede af Satan som en oprørsk figur. Men Satan dukker interessant nok op igen senere i Common Sense, umiddelbart efter at Paine har skitseret sin version af en demokratisk, republikansk styreform; denne gang er det dog som en negativ figur allieret med udemokratiske og kontrarevolutionære kræfter: "He that will promote discord, under a government so equally formed as this, would have joined Lucifer in his revolt" (Paine 1995, 33). Her er rollerne byttet om, og Satan gør ikke oprør mod monarkiets tyranni, men mod den frie og lige republik.

Der er altså tilsyneladende en dobbelthed i den republikanske diskurs, hvor Satan-figurens oprør både må mobiliseres og inddæmmes. (Denne republikanske dobbelthed understreges i øvrigt også af de to forskellige måder, hvorpå Thomas Jefferson og John Adams læste Milton, især hans skildring af Satan' $\left.{ }^{\mathrm{I5}}\right)$. Det er bl.a. denne republikanske modsætning mellem det oprørske og det konservative, som den utopiske funktion i Common Sense arbejder med. ${ }^{16}$

Letters har umiddelbart en tilgang til det republikanske projekt, der ser ud til at være modsat Paines. Men også her findes nogle modsætninger. For Crèvecoeurs fortæller er Uafhængighedskrigen en "unfortunate revolution" (Crèvecoeur 2009, 191), og han understreger sin manglende evne til at begribe de store sammenhænge og abstrakte idéer; han ved blot, at livet nu for ham er blevet sværere og farligere, uden at han selv er skyld i det. Samtidig har han også kvaler ved at droppe forbindelsen ("the antient [sic] connection" (s. 191)) til England og kongen - til trods for at James' (og Crèvecoeurs) egen praksis bestod i at etablere sig langt fra kronens magt, så er der tilsyneladende stadig et behov for en samlende ideologisk figur, der dog holdes på sikker afstand. Crèvecoeur er således blevet beskrevet som en 'monarko-anarkist' (Jehlen 2002). ${ }^{17}$ Men til trods for, at Crèvecoeurs tekst tydeligt har meget til overs for forbindelsen med England og traditionen, dukker der alligevel en interessant ikonoklastisk figur op. Efter først at have kritiseret de republikanske revolutionære for at sætte abstrakte principper over livets basale og konkrete forhold, kommer turen til den engelske konge: Hvis blot han kunne blive udsat for ("be exposed [...] to" (Crèvecoeur 2009, 194)) det, som beboerne i de amerikanske grænseegne oplever, ville han ikke tillade, at der blev ofret mere blod: "The regal character, however sacred, would be superseded by the stronger, because more natural, one of man and father" (s. 194). Her er der tale om, at den ene af kongens "to kroppe" (dvs. på den ene side den konkrete, dødelige og på den anden den udødelige, symbolske krop $^{18}$ ) tilsidesætter den anden, således at den symbolske krop, der inkarnerer kongens samfundsmæssige position og funktion, sættes ud af kraft. Det sker i en retorisk gestus, der ellers synes at give kongen sin respekt, men det er en respekt, der trækker kongen ned på samme niveau som andre dødelige, og hermed installeres en form for egalitær logik - og den etableres netop gennem en erfaring af 'grænsens' prøvelser.

Fremhævelsen af det naturlige frem for det kunstige peger samtidig i retning af tekstens grænse som sådan. I Crèvecoeurs utopiske logik er skriften forbundet med civilisationen og politikkens abstrakte verden (såvel republikansk som royal). På 
den måde kan man sige, at den ikonoklastiske logik også bliver vendt mod skriften som en praksis, der placeres i modsætning til den konkrete, agrare utopi, der kiler sig ind mellem indianernes 'vilde' jægerliv og civilisationens 'skriftbaserede' byliv. ${ }^{19}$ At denne utopi selv først og fremmest er et tekstuelt produkt fremhæver modsætningerne både i Letters som tekst og i utopiens funktion generelt.

\section{Utopisk modstand mod utopien}

Paine skitserer ganske løst, hvordan han forestiller sig en demokratisk styreform indrettet i de kommende selvstændige stater, men han fremhæver, at der netop kun er tale om ufærdige skitser, som han håber, andre vil søge at forbedre. Alligevel er det for Paine i sig selv vigtigt overhovedet at fremsætte et bud: "If there is any true cause of fear respecting independance [sic], it is because no plan is yet laid down. Men do not see their way out" (Paine 1995, 32). Her markeres altså eksplicit en forbindelse mellem fremsættelsen af en utopisk model og muligheden for overhovedet at forestille sig alternative samfund - netop uden at den konkret fremsatte model i sig selv er det væsentlige: Utopien er i sig selv først og fremmest en funktion. Samtidig ses det her, hvordan Paine på én gang artikulerer utopiens tiltrækning og nødvendighed (der må opstilles et alternativ) og modstanden mod utopien (alternativet kan kun antydes). Paine forsøger at løse modsætningen ved i sin tekst at fremskrive et billede af en amerikansk, utopisk potentialitet, og netop på den måde bliver overskridelsens logik som nævnt central i tekstens funktion.

Det er også væsentligt, at Paines tekst og utopi aldrig synes helt at falde på plads i den republikanske orden, John Adams og andre stræbte efter (Adams' tekst Thoughts on Government er bl.a. et angreb på Paines version af republikanisme ${ }^{20}$ ). Der er hele tiden et (utopisk) overskud - jf. i øvrigt også Paines fortsatte revolutionære aktiviteter efter Den amerikanske revolution. Men samtidig er det et overskud, der er afhængigt af også at pege på, at der er en model, en plan, for enden af tunnelen. På den måde er der to utopiske aspekter af Paines tekst, der står i modsætning til hinanden: en utopisk model og en utopisk potentialitet, der hele tiden peger mod overskridelsen. Den painske utopi stræber mod at tage form, men tøver samtidig med at lade formen falde på plads. Det er her, man i Paines tekst kan identificere en 'utopisk modstand mod utopien'. Paines utopiske tekst kan dermed siges at markere et punkt, hvor utopien og den politiske revolution i en vis forstand nærmer sig hinanden, men vel at mærke uden at falde sammen: Utopien fastholdes som et overskud, der ligger uden for politikkens rækkevidde.

Netop denne 'anti-politiske' dimension af utopien bliver foldet langt mere eksplicit ud hos Crèvecoeur. Men også her finder vi to utopiske logikker, der støder mod hinanden. Efter at have beskrevet, hvordan han og hans familie altid har passet sig selv og været hårdtarbejdende, ærlige mennesker, udbryder James: "yet we must perish, perish like wild beasts, included within a ring of fire!" Men umiddelbart efter fortsætter han: "Yes, I will cheerfully embrace that resource, it is a holy inspiration" (Crèvecoeur 2009, 201) - hvorefter han går videre til mere konkret at beskrive sin plan om at flytte ud til indianerstammen. Der etableres altså en bevægelse direkte fra udslettelsen i den forestillede nedbrænding af gård og familie 
til den ubetingede omfavnelse af situationen og dens muligheder. Den samme figur ses også hos Paine, men med en anden konklusion: "Thousands are already ruined by British barbarity [...]. All they now possess is liberty, what they before enjoyed is sacrificed to its service, and having nothing more to lose, they disdain submission" (Paine 1995, 31). Begge steder etableres der på den måde et nulpunkt, der danner udgangspunkt for den utopiske produktion. Det er bevægelsen herfra, der peger i forskellige retninger: I Crèvecoeurs tekst er det en tilbagetrækning, der er tale om, til forskel fra Paines overskridelseslogik.

Den usikre og udsatte situation, James befinder sig i i Letters, er ikke kun en konsekvens af, at vi befinder os i et geografisk rum på kanten af civilisationen, men også af civilisationen som sådan: Det er et resultat af den revolutionære konflikt, som netop er et produkt af civilisationen. I Letters beskriver James, hvordan civilisationen - og ikke mindst det britiske imperium - 'rystes': "That great nation, which now convulses the world" (Crèvecoeur 2009, 197). En rystelse, der ikke blot har karakter af en naturkatastrofe, men netop er et udtryk for, at det civiliserede samfund ryster sig selv. Civilisationens indbyggede ustabilitet åbner på den måde for utopiens nødvendighed - men det er samtidig en utopi, der stadig forskydes. Fra Europa til Amerika, til grænselandets bondeliv, til indianerstammen foregår der en stadig forskydning af det utopiske ikke-steds nulpunkt. Så igen: Hvor Paines utopiske bevægelse består i en stadig overskridelse, består Crèvecoeurs i en stadig tilbagetrækning. I begge tilfælde er det utopiens stadige genopståen ud af utopiens stadigt mislykkede projekt.

Signifikant nok får vi ikke en beskrivelse af livet hos indianerstammen, men kun en forklaring på årsagerne til, at James vil søge derhen samt hans på forhånd dannede forestillinger om, hvordan planen vil lade sig udføre. På den måde får dette nye utopiske projekt også her lov til at blive stående som den rene funktion, det er - det er forskydningen eller tilbagetrækningens bevægelse og funktion som sådan, der bliver fremhævet, mere end det er det konkrete indhold. Det er i den forbindelse bemærkelsesværdigt, hvordan Crèvecoeurs fortæller, James, på én gang fremhæver indianersamfundets konflikt- og problemfri fortræffeligheder, men samtidig under ingen omstændigheder $\emptyset$ nsker at blive som indianerne: Det værste, han kan forestille sig ske under opholdet hos stammen, er, hvis hans børn bliver for integrerede i indianernes væremåder. Indianersamfundet i Crèvecoeurs beskrivelse er ganske vist harmonisk og fredfyldt, og indianerne er lykkelige og lider ingen nød. Men dette perfekte andet samfund skal ikke efterlignes i dets egen ret - det har snarere en specifik funktion i relation til det eksisterende, civiliserede samfund. På den måde støder Crèvecoeurs tekst også på sin egen utopiske modstand mod utopien i form af den tidligere skitserede, landbrugsbaserede utopi: Der ligger en modstand mod utopien i modviljen mod at lade sig opsluge af primitiviteten, og på den måde peges der igen tilbage mod det simple bondeliv, men dermed også mod civilisationen, som også indbefatter politikken og revolutionen. 


\section{Utopiens grænser, utopiens tilbagevenden}

Som nævnt orienterer de to tekster sig mod to forskellige grænser: Paines tekst mod Atlanterhavet som grænsen mod den gamle verden, og Crèvecoeurs tekst mod vildmarkens grænse. På samme måde er det også forskellige utopiske logikker, de får produceret. Eller rettere: De får fremstillet nogle forskellige aspekter af utopiens funktionsmåde - især i forhold til utopiens forhold til revolutionens politik. Og de er ikke blot forskellige, men også modsatrettede, idet Crèvecoeurs utopiske konstruktion på mange måder er en direkte udfordring af Paines. De to tekster viser, hvordan utopien fungerer både som den revolutionære politiks forudsætning (Paine) og som dens modsætning (Crèvecoeur).

Men dette er ikke kun en modsætning mellem de to tekster, men også et modsætningsforhold, der opererer inden for teksterne. I begge tekster opererer både en utopisk tilstand og en utopisk bevægelse, og det er disse forskellige dimensioner, der skurrer mod hinanden som udtryk for utopiens grundlæggende modsætningsfyldte karakter. I Paines konflikt mellem utopisk potentiale og utopisk model. Og i Crèvecoeurs nødvendighed af og modstand imod at løsrive sig fuldstændigt fra civilisationen. På den måde er utopierne både modsatrettede og i aktivt samspil. Selvom Paines utopiske rum er karakteriseret ved en stadig overskridelse og udvidelse, og Crèvecoeurs utopiske rum karakteriseret ved en stadig indskrænkning, er der blot tale om to forskellige måder at producere en utopisk funktion på gennem konstruktionen af et utopisk rums nulpunkt eller ikke-sted som et afgørende element i teksternes strategier.

I Crèvecoeurs og Paines tekster fra Den amerikanske revolution kan vi se, hvordan revolutionen og utopien synes at kredse om hinanden, men uden helt at kunne mødes. Utopien fungerer som et over- eller underskud i forhold til revolutionens politiske logik, der har en anden og i højere grad strategisk karakter - og herved undslipper utopien sin realisering. På den måde producerer teksterne også en modstand mod utopien, der er forbundet med utopiens modsætningsfyldte ontologiske status. Så hvis utopien udgør en dimension i revolutionen, er det samtidig en dimension, der går ud over - og udfordrer - både revolutionens politiske logik og dens ideologiske brudflader.

Derfor vedbliver utopien at fungere som en udfordring, ikke på trods af, men netop fordi den mislykkes. I et af de mest berømte billeder i Common Sense skriver Paine:

16 Now is the seed time of continental union, faith and honor. The least fracture now will be like a name engraved with the point of a pin on the tender rind of a young oak; the wound will enlarge with the tree, and posterity read it in full grown characters. (Paine 1995, 21)

I denne sammenhæng vil jeg læse dette indgraverede navn som utopiens navn: som det tegn, der viser, at utopien mislykkes, men i kraft af dette vedbliver at stå som en udfordring. 


\section{Noter}

I Nogle af de centrale begivenheder er her 'the Stamp Act' (1765), Boston-massakren (1770) og 'the Tea Act' og 'Boston Tea Party' (1773).

2 Om Crèvecoeurs Letters, se f.eks. Ziff 1991, s. 18-33.

3 Se Chordas 2010 for en undersøgelse af nogle af de genrer, som de klassiske utopiske tekster er i dialog med.

4 Min forståelse af utopien er inspireret af - men ikke nødvendigvis fuldstændigt sammenfaldende med - den relativt brede forståelse af utopien, man finder hos teoretikere som Ernst Bloch (1986) og Ruth Levitas (2010), samt af Fredric Jamesons analyser af utopiens funktion (2007b). For en mere snæver, men også indflydelsesrig tilgang, se Sargent 1994.

5 Louis Marin betegner denne proces som en utopisk 'neutralisering' (i modsætning til syntetisering) af modsætninger. For Marin handler utopien ikke om at præsentere løsninger på problemer, men om at pege på grænser. Se Marin 1984.

6 Om revolutionen som (historisk) fænomen, se Nygaard 2008.

7 Herom, se Countryman 2003 og Young 1993.

8 Om republikanismen som et væsentligt element i Den amerikanske revolution, se Pocock 2003, s. 506-52, samt Wood 1992, s. 95-225. Se også Ben-Atar 2007 for en diskussion af forskellige historiografiske tilgange til revolutionen, bl.a. forholdet mellem liberale og republikanske fortolkninger af Den amerikanske revolutions ideologi.

9 Larkin beskriver til gengæld, hvordan senere amerikanske forfattere som Walt Whitman og Herman Melville tog Paine til sig, se Larkin 2005, s. 179-94.

Io Om 'grænsers' betydning for utopien, se Marin 1993.

II Det samme gør Fichtelberg (1994) i sin analyse af det utopiske i Crèvecoeurs tekst. Fichtelberg fokuserer især på, hvordan teksten arbejder med republikanismens modsætninger.

I2 Paine henviser også til Biblen som autoritet i sin argumentation mod monarkiet, se Nelson 2007 for en diskussion af forholdet mellem republikanismens udvikling og forskellige tolkninger af centrale tekststeder i Det Gamle Testamente.

I3 Om Paines litterære strategier og betydning i samtiden, se Larkin 2005, s. 1-67.

I4 For en diskussion heraf, se Wootton 1994, s. 27-41. Paine var i øvrigt heller ikke en støtte af ukontrollerede mobs, se Foner 1977, s. 107-44, om Paines forhold til de forskellige radikale i Philadelphia.

I5 Om Adams' og Jeffersons læsninger af Milton, se Tanner og Collings 2006.

I6 I forhold til dette argumenterer Foner for, at Paines republikanisme stræber efter en forening af den republikanske tradition og det moderne, kommercielle samfund (som den traditionelle republikanisme har et ambivalent forhold til), se Foner 1977, s. 105-6.

I7 Om Crèvecoeurs komplekse forhold til demokrati og monarki, se også Downes 2008, s. 58-83.

I8 Om forestillingen om kongens to kroppe, se Kantorowitcz 1997.

I9 Her er Crèvecoeurs utopi i øvrigt langt hen ad vejen på linje med Jeffersons vision for Den amerikanske republik, som netop var baseret på landbrug i højere grad end på byernes handel og industri.

20 Adams var bl.a. tilhænger af et tokammersystem i modsætning til det etkammersystem, Paine advokerer for i Common Sense. 


\section{Litteratur}

Ben-Atar, Doron (2007): "The American Revolution" i Winks, Robin (red.): The Oxford History of the

British Empire, vol. V: Historiography, Oxford: Oxford University Press, s. 94-113.

Bloch, Ernst (1986): Principle of Hope, 3 vol., Cambridge: MIT Press.

Chordas, Nina (2010): Forms in Early Modern Utopia. The Ethnography of Perfection, Farnham: Ashgate Publishing.

Countryman, Edward (2003): The American Revolution (Revised Edition), New York: Hill and Wang. Crèvecoeur, J. Hector St. John (2009): Letters from an American Farmer, Oxford: Oxford University Press. Downes, Paul (2008): Democracy, Revolution and Monarchism in Early American Literature, Cambridge: Cambridge University Press.

Fichtelberg, Joseph (1994): “Utopic Distresses: Crèvecoeur's Letters and Revolution” i Studies in the Literary Imagination, vol. 27, nr. 1, s. 85-101.

Foner, Eric (1977): Tom Paine and Revolutionary America, Oxford: Oxford University Press.

Jacoby, Russell (2005): Picture Imperfect. Utopian Thought for an Anti-Utopian Age, New York: Columbia University Press.

Jameson, Fredric (2004): "The Politics of Utopia" i New Left Review, nr. 25, s. 35-54.

Jameson, Fredric (2007a): The Political Unconscious. Narrative as a Socially Symbolic Act (Routledge Classics), London/New York: Routledge.

Jameson, Fredric (2007b): "The Desire Called Utopia" i Jameson: Archaeologies of the Future. The Desire Called Utopia and Other Science Fictions, London/New York: Verso, s. 1-233.

Jehlen, Myra (2002): “J. Hector St. John Crèvecoeur. A Monarcho-Anarchist in Revolutionary America", i Jehlen: Readings at the Edge of Literature, Chicago/London: The University of Chicago Press, s. 32-49.

Jendrysik, Mark (2007): “Tom Paine: Utopian?” i Utopian Studies, vol. 18, nr. 2, s. 139-157.

Kantorowitcz, Ernst H. (1997): The King's Two Bodies. A Study in Medieval Political Theology, Princeton: Princeton University Press.

Larkin, Edward (2005): Thomas Paine and the Literature of Revolution, Cambridge: Cambridge University Press.

Levitas, Ruth (2010): The Concept of Utopia (Ralahine Utopian Studies, 3), Bern: Peter Lang. Marin, Louis (1984): Utopics. The Semiological Play of Textual Spaces, New York: Humanity Books. Marin, Louis (1993): "Frontiers of Utopia. Past and Present", i Critical Inquiry, vol. 19, nr. 3, s. 397-420. Milton, John (1993): Paradise Lost (Norton Critical Edition), New York: W. W. Norton \& Co.

Nelson, Eric (2007): “Talmudic Commonwealthsmen' and the Rise of Republican Exclusivism” $i$ The Historical Journal, vol. 50, nr. 4, s. 809-35.

Nygaard, Bertel (2008): "Revolutionen som historisk handlingshorisont", i Kontur, nr. 18, s. 3-12. Paine, Thomas (1995): Collected Writings (The Library of America Series, 76), New York: Penguin. Pocock, J. G. A. (2003): The Machiavellian Moment. Florentine Political Thought and the Atlantic Republican Tradition, Princeton/Oxford: Princeton University Press.

Sargent, Lyman Tower (1994): “The Three Faces of Utopianism Revisited”, i Utopian Studies, vol. 5, nr. 1, s. 1-37.

Tanner, John S. og Collings, Justin (2006): "How Adams and Jefferson read Milton and Milton Read Them" i Milton Quarterly, vol. 40, nr. 3, s. 207-19.

Warner, Michael (1990): The Letters of the Republic. Publication and the Public Sphere in EighteenthCentury America, Cambridge/London: Harvard University Press.

Wood, Gordon S. (1992): The Radicalism of the American Revolution, New York: Alfred A Knopf. 
Wootton, David (1994): "Introduction: The Republican Tradition: From Commonwealth to Common Sense", i Wootton (red.): Republicanism, Liberty, and Commercial Society, 1649-1776, Stanford: Stanford University Press, s. 1-41.

Young, Alfred F. (1993): “Afterword: How Radical Was the American Revolution?”, i Young (red.): Beyond the American Revolution. Explorations in the History of American Radicalism, DeKalb: Northern Illinois University Press, s. 317-64.

Ziff, Larzer (1991): Writing in the New Nation. Prose, Print and Politics in the Early United States, New Haven/London: Yale University Press.

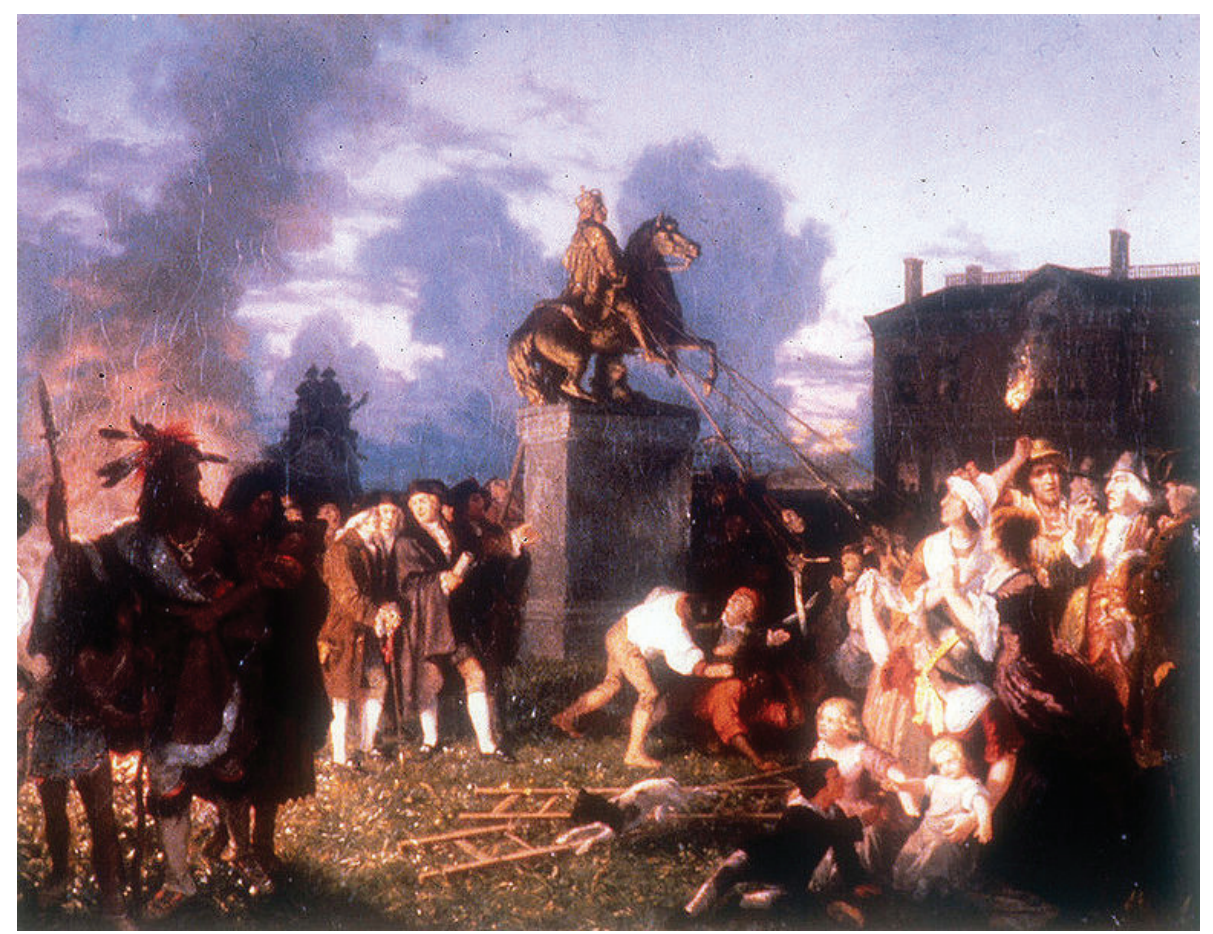

Johannes Adam Simon Oertel: Pulling Down the Statue of King George III, N.Y.C. Olie på lærred, ca. 1859 